\title{
CZECH AGRARIAN FOREIGN TRADE COMPARATIVE ADVANTAGES DISTRIBUTION: TRANSFORMATION PROCESS
}

Luboš SMUTKA, Department of Economics, Faculty of Economics and Management, Czech University of Life Sciences Prague, Kamýcká 129, Praha Suchdol, 16521, Czech Republic; smutka@pef.czu.cz (coresponding author)

Miroslav SVATOŠ, Department of Economics, Faculty of Economics and Management, Czech University of Life Sciences Prague, Kamýcká 129, Praha Suchdol, 16521, Czech Republic, svatos@pef.czu.cz

Mansoor MAITAH, Department of Economics, Faculty of Economics and Management, Czech University of Life Sciences Prague, Address: Kamýcká 129, Praha Suchdol, 16521, Czech Republic; maitah@pef.czu.cz

\begin{abstract}
This paper primarily focuses on Czech agrarian foreign trade comparative advantage issues. The structure and comparative advantages distribution are analyzed in the period before (2001) and after the Czech EU accession (2015/2016). The main central aim of this paper is to identify and analyze changes in comparative advantages distribution and trade commodity structure which have occurred. Trade structure and comparative advantages distribution are analysed in relation to the EU and rest of the World (Developing countries, OECD members, CIS, etc.). Commodity structure (we applied HS system) is analysed specifically in relation to unit value development, trade volume development and comparative advantages distribution development. To successfully accomplish the above mentioned objectives, this paper applies Lafay index and Trade balance index. The results derived from individual analyses are highlighted through the "Product mapping method". The product mapping matrix divides the entire set of exported products into 4 groups. The LFI index has been chosen for the "product mapping" approach because of its ability to take into consideration only those transactions which are truly related to individual countries' trade performance. The TBI index has been utilized for its ability to divide the products according to their real trade performance into the above specified four quadrants. In the analysed period, Czech agrarian trade increased its dependency on EU Countries. The share of EU countries in regards to Czech agrarian trade turnover has increased from $78 \%$ to nearly 90\%. Czech agrarian exports are dominated by low processed and semi-processed aggregations having a low unit value. On the other hand, imports can be characterized by a much higher unit value and a much higher processing level. Unfortunately, the unit value of Czech agrarian exports has been constantly decreasing on the other hand the unit value of imports is increasing. Czech trade comparative advantages exist in relation to the following set of products: HS10, HS12, HS01, HS04, HS15, HS24, HS22, HS11, HS17, HS03, HS16, HS09, HS13 and HS14.
\end{abstract}

Keywords: Czechia, agrarian trade, comparative advantages, distribution, changes, development, unit value, volume, value

\section{INTRODUCTION}

Czech agrarian foreign trade changed its structure during the last few years. The value and volume development significantly affected the character of export and import activities. Only in the period from 2001 through 2016 its export value increased from 49 billion CZK to 201.5 billion CZK. The growth of exports even exceeded the growth of imports (from 69 billion CZK up to 224.7 billion CZK). The share of negative trade balance in relation to total agrarian trade turnover value was significantly reduced from $17 \%$ to less than $5 \%$. The level of import by export coverage ration also significantly increased from $71 \%$ up to cc $90 \%$. During the analysed period, commodity structure in particular recorded significant changes. Finalized and especially semi-finalized food products increased their share both in export and also import activities (Pohlova, Mezera, 2014). The mentioned trend is related to two factors: the growth of economic power and also the restructuralization of the Czech foodstuff market (the significant influence of foreign direct investments. Territorial structure has become more specifically concentrated on European countries (Burianová, Belová, 2012). The long term orientation especially on the European region is considered to be the weakness of the Czech agrarian trade. Many experts in this case have been speaking about the necessity to diversify Czech agrarian trade territorial structure (Pohlová, Mezera 2014; Kancs, Ciaian, 2010; etc.).

This article analyses the basic transformation trends related to Czech agrarian foreign trade territorial and commodity structure development and restructuring in the period of 2001 to 2016. Czech agrarian foreign trade structure and value were affected in the past by the significant changes related to Czech agrarian policy and economy and trade performance - especially in relation to the EU accession process and Czech membership in the EU (Lukas, 1998; Smutka, Steininger, Maitah, 2015; Svatos, Maitah, Belova, 2013; Honig et al., 2017a; 2017b ). The transformation process

Copyright (C) 2017 The Authors. Published by Aleksandras Stulginskis University. This is an open-access article distributed under the terms of the Creative Commons Attribution License (CC-BY 4.0), which permits unrestricted use, distribution, and reproduction in any medium, provided the original author and source are credited. 
especially in the period before Czech accession was not really a positive one (Presova et al., 2008). Czech agrarian imports recorded extremely fast growth rate in comparison to the exports value. The Czechia also reduced the importance of nonEU territories and began focusing its trade activities specifically on European partners (Ferto, 2008; Lukas, 1998). On the other hand the period immediately after the accession significantly encouraged not only the export, but also import performance (Svatos, 2008). During the first years of Czech EU membership the import value was growing even faster in comparison to export value development.

\section{DATA AND METHODS}

This paper aims to identify changes which have occurred during the analysed time period from 2001 to 2016. Except for individual changes, other individual factors responsible for them are specified. Territorial structure is analysed both in relation to the EU countries and also in relation to the "third countries" (e.g. CIS, OECD, European countries without the EU28, World and World without the EU, Developing countries). The Commodity structure (we applied HS system dividing agrarian trade into 24 commodity groups) is analysed especially in relation to added value development and distribution. The paper also specifies the distribution of comparative advantages both in relation to EU market and also in relation to the rest of the world. To reach the above mentioned objectives, the paper applies the competitiveness analyses (Lafay index and trade balance index). The results coming from individual analyses are highlighted through the modified "Product mapping method". Data sources for individual analyses are following: UN COMTRADE, Czech statistical office. As it was mentioned before, we applied several different types of indices to measure the level of Czech agrarian trade competitiveness.

The Balassa index (Balassa, 1965) tries to identify whether a country has a "revealed" comparative advantage rather than to determine the underlying sources of comparative advantage. The index is calculated as follows:

$$
R C A=\left(X_{i j} / X_{i t}\right) /\left(X_{n j} / X_{n t}\right)=\left(X_{i j} / X_{n j}\right) /\left(X_{i t} / X_{n t}\right)
$$

where $x$ represents exports, $i$ is a country, $j$ is a commodity and $n$ is a set of countries, $t$ is a set of commodities.

Vollrath index (Vollrath, 1991) allows us to assess trade flows not only in terms of export values, while also taking into account values of imports. Furthermore, in contrast to Balassa's index, Vollrath index is symmetric, with positive values indicating a revealed comparative advantage and negative values a revealed a comparative disadvantage. The revealed competitiveness is calculated as the difference between relative export advantage (RXA), which is the equivalent to the original Balassa index (RCA), and its counterpart, relative import advantage (RMA).

$$
R M A=\left(M_{i j} / M_{i t}\right) /\left(M_{n j} / M_{n t}\right)
$$

Where $\mathrm{M}$ accounts for imports.

$$
R X A=R C A=\left(X_{i j} / X_{i t}\right) /\left(X_{n j} / X_{n t}\right)
$$

The measure of Vollrath is the revealed competitiveness (RC), expressed as:

$$
R C=\ln R X A-\ln R M A
$$

The next index used in this paper is the Lafay index (Lafay, 1992). Using this index we consider the difference between each item's normalized trade balance and the overall normalized trade balance. Using the LFI index we can focus on the bilateral trade relations between the countries and regions. For a given country, $i$, and for any given product $j$, the Lafay index is defined as:

$$
L F I_{j}^{i}=100\left(\frac{x_{j}^{i}-m_{j}^{i}}{x_{j}^{i}+m_{j}^{i}}-\frac{\sum_{j=1}^{N}\left(x_{j}^{i}-m_{j}^{i}\right)}{\sum_{j=1}^{N} x_{j}^{i}+m_{j}^{i}}\right) \frac{x_{j}^{i}+m_{j}^{i}}{\sum_{l=1}^{N} x_{j}^{i}+m_{j}^{i}}
$$

where $\mathrm{x}_{\mathrm{j}}^{\mathrm{i}}$ and $\mathrm{m}_{\mathrm{j}}^{\mathrm{i}}$ are exports and imports of product $j$ of country $i$, towards and from the particular region or the rest of the world, respectively, and $N$ is the number of items. Positive values of the Lafay index indicate the existence of comparative advantages in a given item; the larger the value the higher the degree of specialization. (Zaghini, 2003)

The next part of the analysis presented in this paper was conducted using the analytical tool, called "products mapping". This tool enables the user to assess leading exported products from two different points of view, i.e. domestic trade-balance and international competitiveness. (Widodo, 2009). The Revealed Symmetric Comparative Advantage (RSCA) by Dalum et al.(1998) and Laursen (1998) is the indicator of comparative advantage and Trade Balance Index (TBI) by Lafay (1992) is the indicator of export-import activities.

The RSCA index is a simple decreasing monotonic transformation of Revealed Comparative Advantage (RCA) or Balassa index. RSCA index is formulated as follows:

$$
R S C A=\left(R C A_{i t}-1\right) /\left(R C A_{i j}+1\right)
$$


The values of RSCA $\mathrm{A}_{\mathrm{ij}}$ index can vary from minus one to one. $\mathrm{RSCA}_{\mathrm{ij}}$ greater than zero implies that country $i$ has comparative advantage in a group of products $j$ (Dalum et al.,1998)

Trade Balance Index (TBI) is employed to analyze whether a country has specialization in export (as net-exporter) or in import (as net-importer) for a specific group of products. TBI is simply formulated as follows:

$$
T B I_{i j}=\left(x_{i j}-m_{i j}\right) /\left(x_{i j}+m_{i j}\right)
$$

where TBIij denotes trade balance index of country $i$ for product $j ; x_{i j}$ and $m_{i j}$ represent exports and imports of group of products $j$ by country $i$, respectively (Lafay, 1992). A country is referred to as a "net-importer" in a specific group of products if the value of TBI is negative, and as a "net-exporter" if the value of TBI is positive. (Widodo, 2009).

Because the original approach does not take into consideration the real intensity/influence of imports (see the RCA structure), we decided to slightly modify the original "product mapping approach" and we replaced the RSCA index with the LFI index to get more precise data about the real competitiveness of the Czech agrarian trade commodity structure. Figure 1 represents the modified matrix for the distribution of the entire set of exported products into 4 groups according to the two selected indicators. The advantage of the above applied modification is its ability to more accurately divide the products according to their real trade performance into the above specified four quadrants. While the first approach provides a possibility to identify the comparative advantage on a general level, the second approach provides the possibility to specify the comparative advantages on the base of real bilateral trade performance.

\begin{tabular}{|c|c|c|c|}
\hline \multirow{2}{*}{ 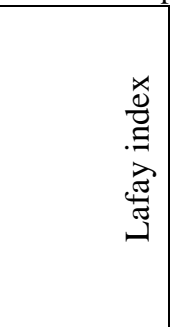 } & $\begin{array}{l}\text { 全 } \\
\text { 皃 }\end{array}$ & $\begin{array}{l}\text { Group B: } \\
\text { Comparative Advantage } \\
\text { Net-importer } \\
(\text { LFI }>0 \text { and } \mathrm{TBI}<0) \\
\end{array}$ & $\begin{array}{l}\text { Group A: } \\
\text { Comparative Advantage } \\
\text { Net-exporter } \\
(\mathrm{LFI}>0 \text { and } \mathrm{TBI}>0) \\
\end{array}$ \\
\hline & $\frac{\stackrel{\vartheta}{v}}{\stackrel{I}{J}}$ & $\begin{array}{l}\text { Group D: } \\
\text { Comparative disadvantage } \\
\text { Net-importer } \\
(\mathrm{LFI}<0 \text { and } \mathrm{TBI}<0)\end{array}$ & $\begin{array}{l}\text { Group C: } \\
\text { Comparative disadvantage } \\
\text { Net-exporter } \\
(\text { LFI }<0 \text { and } \mathrm{TBI}>0)\end{array}$ \\
\hline \multicolumn{2}{|c|}{$\begin{array}{l}\text { Czech Agrarian Foreign Trade } \\
\text { Commodity Structure }\end{array}$} & TBI $<0$ & TBI >0 \\
\hline
\end{tabular}

Source: own modification and processing (2016)

\section{RESULTS AND DISCUSSION}

When looking at the territorial structure of the Czech agricultural trade, it is apparent that it is more and more focused specifically on EU-countries. The EU share in the Czech agricultural trade reaches about $90 \%$ in the long-term. The Czech agricultural exports and also imports are based on a relatively small number of commodity aggregations, which represent a substantial part of the realized trade performance. However the value of imports is constantly increasing, the level of self-sufficiency is not decreasing. Czech exports are able to compensate for even the growth of imports especially through its increasing added value. The key aspect of the Czech agrarian trade is its competitiveness. The Czech agrarian sector still does not finish the process of its restructuring and its commodity structure profile is constantly changing. The value of Czech agrarian trade is typical especially because of its specific character in relation to individual partners/partner territories. As it was mentioned already before Czech agrarian trade is heavily focused on European territory. If we compare the period between 2001 and 2016, it is possible to highlight the significant growth of export and import value performance in relation to all main territories representing the main Czech agrarian trade partners. In addition, the Czech agrarian export growth rate exceeded the import growth rate especially in relation to the EU28, OECD members and also in relation to non-European countries. The only regions increasing their imports to the Czech Republic faster than the Czech Republic exported to them are European countries without the EU and CIS members. The Czech Republic also significantly reduced its negative trade balance share both in relation to total agrarian trade turnover and export value. In this case the situation improved especially in relation to the EU28, other European countries and OECD members. During the last 15 years, Czech agrarian trade became extremely concentrated. The concentration is not related only to territorial structure, but it is also related to its commodity structure. The specific feature of Czech agrarian foreign trade performance is its competitiveness. The Czech Republic is an industrial country and our comparative advantages in particular, exist outside of our agricultural sector.

The existence of comparative advantages is proved through the application of LFI and RSCA indices taking into consideration only agricultural trade performance (Other sectors are not included into comparative advantages calculation). Both methods provides almost the same results, but because of limited size of this paper only modified product mapping approach results are specified (see Graph 1). On the base of applied approach, it is evident that the Czech agrarian trade commodity structure has been significantly changing its character. The commodity structure is still looking for its optimal state. It is also possible to see that comparative advantages are especially influenced by bilateral relations. The Czech Republic is not competitive at a general level, but it is able to get comparative advantages at least at the bilateral level especially because of our EU membership and also because of the existence of special agreements between the EU and selected partners. 


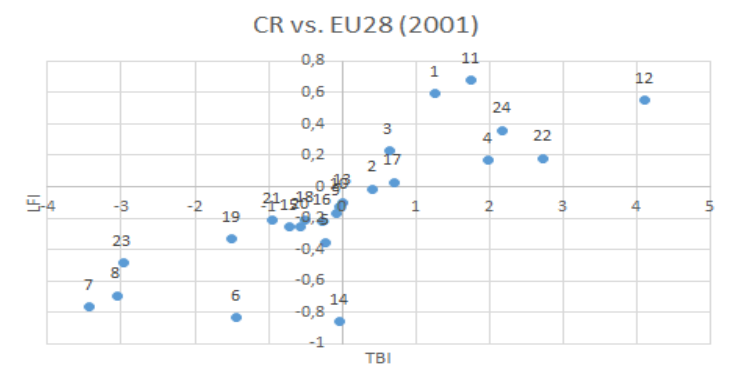

CR vs. European countries without EU28 and CIS (2001)

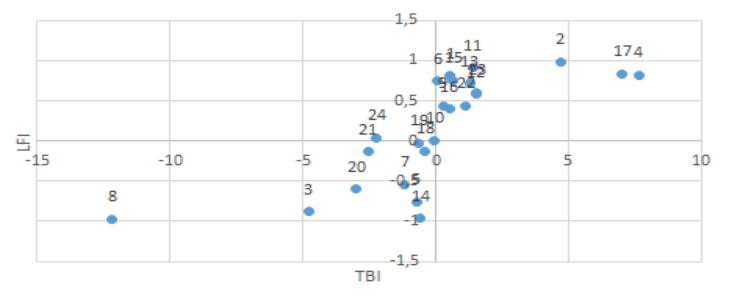

CR vs. OECD (2001)

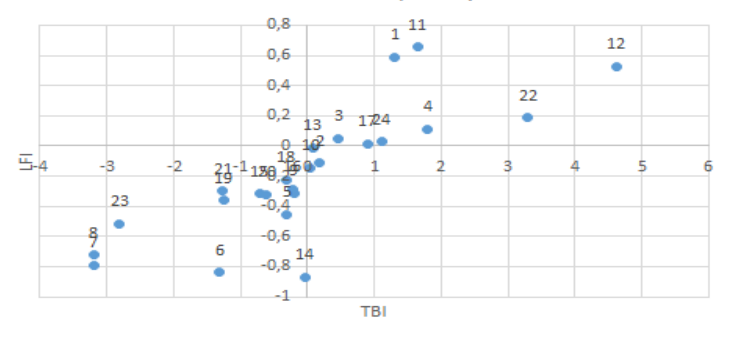

CR vs. CIS (2001)

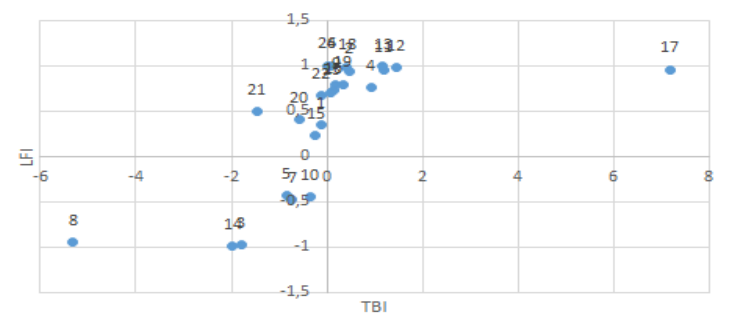

CR vs. World without EU28 (2001)

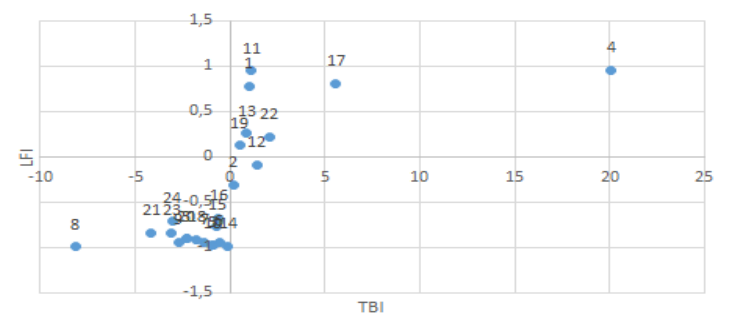

CR vs. Developing countries(2001)

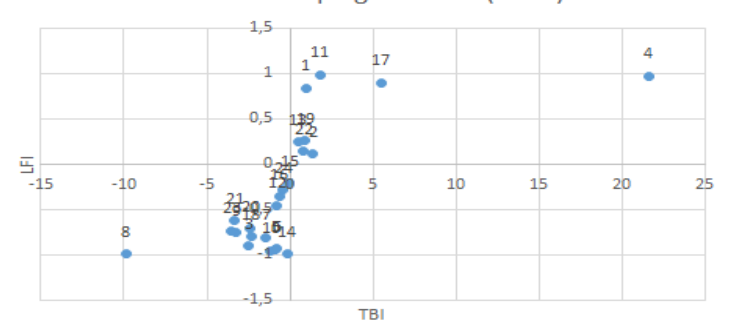

TBI

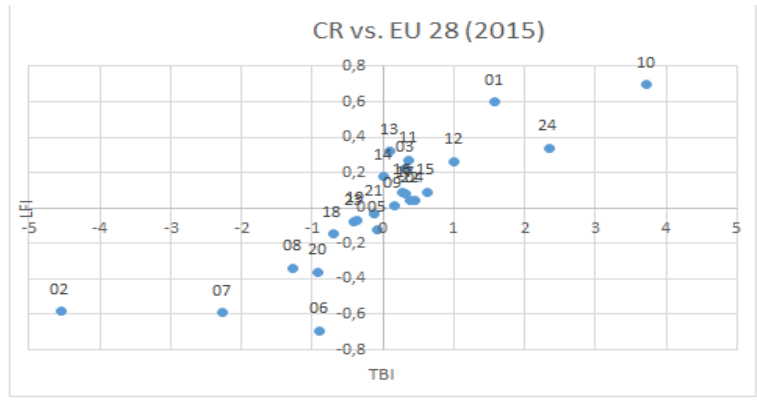

CR vs. European countries without EU28 and CIS (2015)

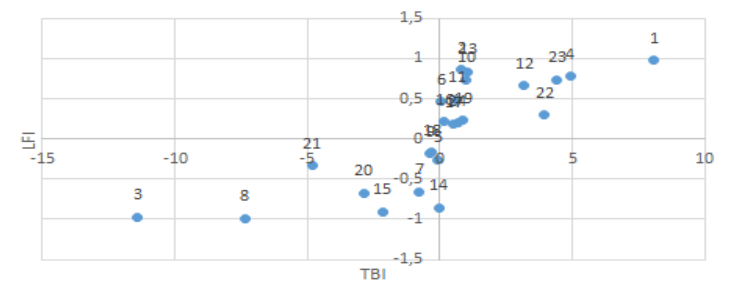

CR vs. OECD (2015)

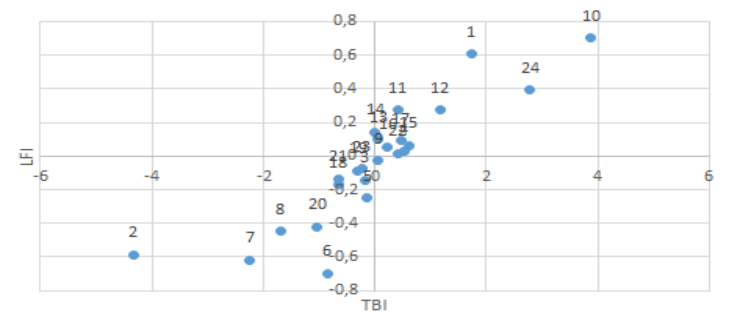

CR vs. CIS (2015)

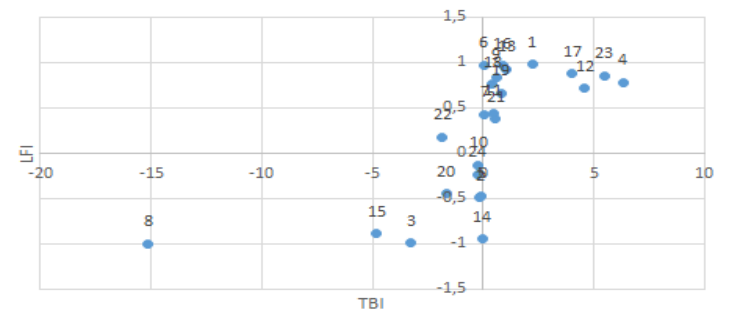

CR vs. World without EU28 (2015)

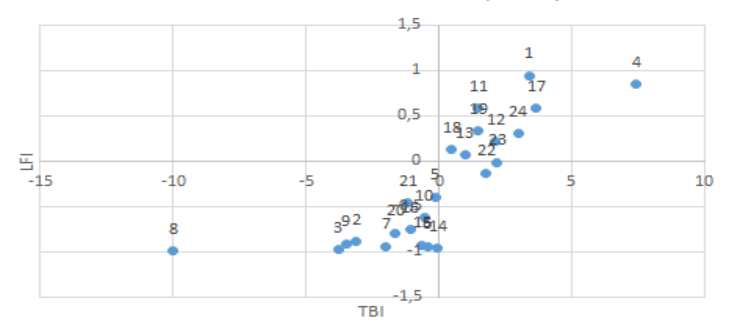

CR vs. Developing countries(2015)

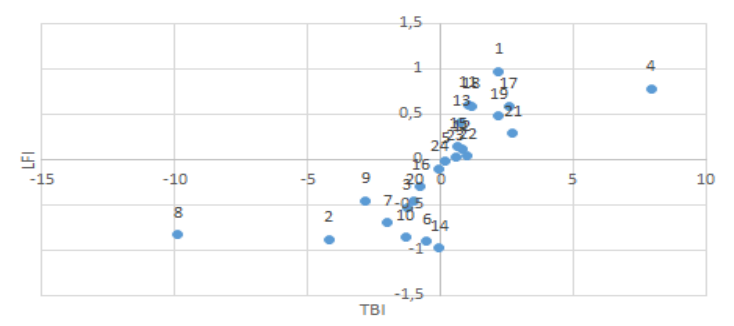

Source: own processing, 2016

Graph 1. Czech agrarian trade commodity structure formation in relation to individual analysed groups of countries (modified product mapping approach) 


\section{Distribution of comparative advantages in relation to different groups of countries}

The following Graph 1 provides the overview of the Czech agrarian trade commodity structure distribution according to LFI and TBI index value in relation to the selected groups of countries. The analysis provides not only a comparison of different commodity structures for individual groups of countries. It also provides a possibility to compare the state of commodity structure between 2001 and 2016. The results coming from individual analyses provide a very interesting overview of current and past situations. The significant dynamics of commodity structure development can be seen both in relation to the LFI and the TBI index. The structure of agrarian trade has still not stabilized and agricultural trade is still looking to find an ideal state. The significant changes in Czech agrarian trade competitiveness between 2001 and 2016 can be seen especially in relation to EU28 and other European countries. The share of A group products in total agrarian exports significantly increased between the years 2001 and 2016. On the other hand the share of items located in group D has significantly reduced. Developing countries did not change their role in Czech agrarian export and import activities according to TBI and LFI values distribution. The Czech Republic is heavily focused on trade activities realized in relation to developed and especially European countries. The majority of Czech agrarian trade value is realized on the base of a proved comparative advantage in relation to individual groups of partners (almost $60 \%$ of total exports). The strong cornerstone of Czech competitiveness is a much lower unit price (2016) of exports (average value of export unit price reached $10.3 \mathrm{CZK} / \mathrm{kg}$ ) in comparison to imports (average value of import unit price reached $28.5 \mathrm{CZK} / \mathrm{kg}$ ). This situation is a long-term weakness of Czech agrarian trade e.g. in 2001 the average export respectively import unit price reached $16 \mathrm{CZK} / \mathrm{kg}$ respectively $22 \mathrm{CZK} / \mathrm{kg}$. The competitiveness of Czech exports is based on constantly decreasing unit price value and export price/import price unit ratio.

Developed countries (OECD members) - the majority of Czech agrarian trade activities is realized in relation to Developed countries. The specific role within that group of countries is kept by EU28 members (see below). Czech agrarian exports and imports increased during the analysed time by $353 \%$ respectively $254 \%$. Commodity structure of Czech agrarian trade recorded significant changes during the analysed time period. The share of individual groups of agrarian trade items recorded the following changes. Group A increased from cc $40 \%$ to cc $48 \%$, Group B and C experienced only a fractional change (from 6.6\% to 5.6\%) and the share of group D in total agrarian trade performance was reduced from cc $54 \%$ to $47 \%$.

EU28 - are the main trade partners of the Czech Republic (their share in total Czech agrarian trade within the analysed time period was cc $78 \%$ respectively $88 \%$ ). During the analysed time period EU trade experienced significant restructuring. The value of exports and imports increased by cc $350 \%$ respectively cc $268 \%$. The share of Group A transactions in total agrarian trade increased from $38.55 \%$ to $55.21 \%$. The share of Groups B and C was reduced from cc $4.74 \%$ to $0 \%$. And the share of Group D was reduced from $56.7 \%$ to $44.8 \%$. The Czech exports to the EU28 became, during the analysed period, more focused on competitive items.

Developing countries (also transitional or emerging economies) - represent only a minor share of Czech agrarian trade - cc 11\%. During the analysed time period, the share of those countries was significantly reduced (in 2001 it was cc 20\%). Despite significant share reduction - Czech agrarian exports and imports realized in relation to developing countries, significant growth by cc $120 \%$ respectively cc $80 \%$. The growth rate was significantly lower in comparison to OECD respectively EU28 members. The commodity structure (according to TBI and LFI) recorded the following changes during the analysed time period. The share of Group A increased from $36 \%$ to $49 \%$, the share of Groups B and C is extremely low at only cc $2.2 \%$ and the share of Group D recorded a significant reduction from $64 \%$ to $49 \%$.

On the base of the results coming from the applied approaches, it is possible to see that during the last fifteen years, development has affected the level of Czech agrarian trade concentration. While in 2001 the share of TOP5 and TOP10 commodity items in total agrarian exports reached 52\% respectively 76\%, in 2015 it was $41 \%$ respectively $70 \%$. The significant weakness of the Czech agrarian trade is its ability to generate added value. Czech agrarian trade is still growing, especially through constant volume growth and through low export unit price. While the value of Czech agrarian exports and imports increased 4.1 times respectively 3.2 times, the volume of Czech agrarian trade especially, exports increased more than 6.35 times. The export volume is growing much faster in comparison to import volume (2.5 times). During the monitored time period (2001 - 2015), the volume of Czech exports increased by 16.5 million tonnes, while the import volume increased by 4.6 million tonnes. The result was the significant disproportion between the Czech agrarian trade export and import unit price. While in 2001 the export and import unit prices reached $16.01 \mathrm{CZK} / \mathrm{kg}$ respectively 22.25 $\mathrm{CZK} / \mathrm{kg}$, in 2015 it was about $10.31 \mathrm{CZK} / \mathrm{kg}$ respectively $28.55 \mathrm{CZK} / \mathrm{kg}$. The negative results are especially influenced by the high portion of unprocessed water and wheat in Czech agrarian export. If we exclude those two groups of items from our trade performance, the difference between Czech export and import prices is marginal $28.5 \mathrm{CZK} / \mathrm{kg}$ vs. 30.3 $\mathrm{CZK} / \mathrm{kg}$. The Czech agrarian exports realized under the group A (positive values of LFI and TBI) are suffering because of constantly increasing imports. While the share in 2001 under the group A realised only 17\% of total imports in 2015, it was already cc 33\%. On the other hand the share of export values realized under the group A within the same period increased only from cc $52.5 \%$ to $57.5 \%$.

\section{CONCLUSIONS}

On the base of the results coming from the applied approaches, it is possible to see that during the last fifteen years, development has affected the level of Czech agrarian trade concentration. While the territorial structure has become even more concentrated, the commodity structure has become more diversified. The export commodity structure is especially based on the set of commodities that have comparative advantages - especially at the bilateral level. While the Czech 
trade is quite competitive, especially in relation to the European countries (EU28, CIS and the rest of Europe), the competitiveness in relation to other territories (especially developing countries and not European OECD members) is limited. The modified product mapping approach proved that the process of Czech agrarian trade re-structuralization in relation to traditional partners (especially the Europeans) is still running and it is close to its final state. In relation to other partners, the trade profile is still developing and we are very far from the final state of commodity structure. The important question related to the current and especially the future of Czech agrarian trade profile is its competitiveness. The combination of especially RCA, TBI and LFI analyses proved the existence of comparative advantages in relation to the following set of aggregations: (at the level of bilateral agreements): Cereals, Live animals, Oil seeds, Tobacco products, Dairy products, Sugar, Vegetable oils, saps and plaiting materials, Milling products, Beverages and alcohol. In relation to the rest of the World (without EU28 internal trade) Czech agrarian trade is competitive especially in relation to the following commodity groups: Live animals, Dairy products, Sugar, Beverages and alcohol, Oil seeds, Preparation of cereals, Milling products, Cocoa preparations, Vegetable saps and Tobacco products.

\section{ACKNOWLEDGEMENT}

The paper is processed with financial support of IGA, FEM, CULS Prague. Grant number 20171024 - The analysis of Czech agrarian trade commodity structure.

\section{REFERENCES}

1. Balassa, B. 1965. Trade liberalization and "revealed" comparative advantage. The Manchester School of Economics and Social Studies, Vol. 33, Iss. 2, pp. 99-123.

2. Burianova, J., Belova, A. 2012. The competitiveness of agricultural foreign trade commodities of the CR assessed by way of the Lafay Index. Agris On-line Papers in Economics and Informatics, Vol. 4, Iss. 4, pp. 27-36.

3. Dalum, B., Laursen, K. and Villumsen, G. 1998. Structural Change in OECD Export Specialization Patterns: De-specialization and 'Stickiness'. International Review of Applied Economics, Vol. 12, pp. 447-467. https://doi.org/10.1080/02692179800000017

4. Fertõ, I. 2008. The evolution of agri-food trade patterns in Central European countries. Post-Communist Economies, Vol. 20, Iss. 1, pp. 1-10. https://doi.org/10.1080/14631370701865680

5. Kancs, D., Ciaian, P. 2010. Factor content of bilateral trade: The role of firm heterogeneity and transaction costs. Agricultural Economics, Vol. 41, Iss. 3-4, pp. 305-317.

6. Honig, V., Linhart, Z., Prochazka, P. 2017. Biobutanol from local bio-wastes. 26th International Scientific Conference on Agrarian Perspectives - Competitiveness of European Agriculture and Food Sectors. Czech Univ Life Sci, Fac Econ \& Management, Prague, pp. 102-108.

7. Honig, V., Linhart, Z., Prochazka, P. 2017. Hydrotreated vegetable oil \}HVO] for local bio-wastes. 26th International Scientific Conference on Agrarian Perspectives - Competitiveness of European Agriculture and Food Sectors. Czech Univ Life Sci, Fac Econ \& Management, Prague, pp. 109-115.

8. Lafay, G. 1992. The measurement of revealed comparative advantages. In: DAGENAIS, M. G. and MUET, P. A. (eds.), London: International Trade Modeling, Chapman \& Hill. https://doi.org/10.1007/978-1-4757-2150-8_10

9. Laursen, K. 1998. A Comparison of Measures of International Specialisation. paper to appear as Chapter 3 in: Laursen (1998), A Neo-Schumpeterian Perspective on the Determinants and Effects of International Trade Specialisation. IKE-Group, Aalborg University, Aalborg

10. Lukas, Z. 1998. Agricultural reforms in the CEFTA and EU eastern enlargement. Most, Vol. 8, Iss. 2, pp. $143-166$. https://doi.org/10.1023/A:1009503109801

11. Mezera, J., Pohlova, K. 2014. Analysis of development of czech foreign trade in foods and beverages. Agris On-line Papers in Economics and Informatics, Vol. 6, Iss. 4, pp. 121-131.

12. Presová, R., Tvrdoň, O., Živělová, A. 2008. Importance of intrastat in EU intra-Communtty trade. Acta Universitatis Agriculturae et Silviculturae Mendelianae Brunensis, Vol. 56, Iss. 3, pp. 175-186. https://doi.org/10.11118/actaun200856030175

13. Smutka, L., Steininger, M., Maitah, M. et al. 2015. The Czech agrarian foreign trade - ten years after the EU accession. Conference: 24th International Scientific Conference on "Agrarian Perspectives - Global Agribusiness and the Rural Economy 2015”, Vol. 25, pp. 385-392, Czech University of Life Sciences Prague.

14. Svatos, M., Maitah, M., Belova, A. 2013. World sugar market-basic development trends and tendencies. Agris On-line Papers in Economics and Informatics, Vol. 5, Iss. 2, pp. 73-88.

15. Svatos, M. 2008. Selected trends forming European agriculture. Agricultural Economics - Zemědělská ekonomika, Vol. 54, No. 3, pp. 93-101.

16. Vollrath, T. L., 1991. A Theoretical Evaluation of Alternative Trade Intensity Measures of Revealed Comparative Advantage, Weltwirtschaftliches Archiv. Review of World Economics, Vol. 127, Iss. 2, pp. 265-280.

17. Zaghini, A., 2003. Trade advantages and specialization dynamics in acceding countries. Working paper No. 249. Frankfurt am Main, Germany: European central bank, pp. 4-15.

18. Widodo, T., 2009. Comparative Advantage: Theory, Empirical Measures and Case Studies. Review of Economic and Business Studies, Vol. 4, pp. 57-82. 